\title{
EVALUATION OF IN VITRO CYTOTOXIC ACTIVITY OF CHLOROFORM EXTRACT OF SIDA ACUTA BURM.F.
}

\author{
LAKSHMI KANTA KANTHAL ${ }^{1 *}$, KAUSIK BHAR $^{2}$, PAGIDIGUMMULA RAVALI $^{3}$
}

${ }^{1}$ Department of Pharmacology, Koringa College of Pharmacy, Korangi, Tallarevu, Andhra Pradesh, India. ${ }^{2}$ Department of Pharmaceutical Chemistry, Koringa College of Pharmacy, Korangi, Tallarevu, Andhra Pradesh, India. ${ }^{3}$ Department of Pharmaceutical Chemistry, Pulla Reddy Institute of Pharmacy, Hyderabad, Telangana, India. Email: lkkhaldia@gmail.com

Received: 21 August 2016, Revised and Accepted: 07 November 2016

ABSTRACT

Objective: The aim of the present work was to investigate the in vitro cytotoxic activity of chloroform extract of Sida acuta Burm.f.

Methods: The in vitro cytotoxic activity of chloroform extract was performed by 3-(4, 5-dimethyl thiazol-2-yl)-2, 5-diphenyl tetrazolium bromide assay method against A-431 (human epidermoid carcinoma) and HeLa (human cervical cancer) cell lines.

Results: The various concentrations of crude chloroform extract (1000, 500, 250, 125, and $62.5 \mu \mathrm{g} / \mathrm{ml}$ concentration) of $S$. acuta whole plant were performed for cytotoxic activity. Effect of inhibition of cell growth showed significantly cytotoxic against A-431 cell lines (human epidermoid carcinoma) with an inhibit cell growth by $50 \%$ ( $\mathrm{IC}_{50}$ ) of $375 \pm 0.00$ and HeLa cell lines (human cervix carcinoma) with an IC ${ }_{50}$ of $610.00 \pm 2.5$. The results obtained from the study indicate significant cytotoxic activity. The result of anticancer activity study in cell lines of the extract indicates that $\mathrm{S}$. $a c u t a$ has anticancer activity against A-431-human epidermoid carcinoma and HeLa-human cervical cancer cell lines.

Conclusion: The present study concluded that the chloroform extract of $S$. acuta Burm.f. possess potent cytotoxic activity.

Keywords: Sida acuta Burm.f., Chloroform extract, Cytotoxic activity, Inhibit cell growth by $50 \%$.

(C) 2017 The Authors. Published by Innovare Academic Sciences Pvt Ltd. This is an open access article under the CC BY license (http://creativecommons. org/licenses/by/4. 0/) DOI: http://dx.doi.org/10.22159/ajpcr.2017.v10i2.14810

\section{INTRODUCTION}

Medicinal plants continue to be widely practiced on many accounts. In particular, higher plants have been the source of medicinal agents since the earliest times, and today, they continue to play dominant role in the primary health care of about $80 \%$ of the world's population [1]. Natural products and medicinal agents are also an essential feature in the health-care system of the remaining $20 \%$ of the population residing mainly in developed countries with more than $50 \%$ of all drugs in clinical use having a natural product origin [2]. Herbal drug is still the strength of about $75-80 \%$ of the world population. Herbalism is the ancient form of healthcare known to humans [3]. It was a fundamental part for the improvement of the modern society. Herbal drugs are used in therapeutics to prevent and treat diseases and ailments or to support health and healing [4].

In various countries, herbal medicines may also include by habitual, natural organic, or inorganic active constituents which are not of plant resource. Herbal drug is a principal component in habitual medicine and a general constituent in Ayurvedic, Homeopathic, Naturopathic, and other medication systems. Herbs are generally considered as safe because they belong to innate sources [5]. This research provides a widespread scheme of herbal medicines and anticipates to elucidate the therapeutic efficacy of different herbal medicines, undesirable drug reactions, drug interactions, standardization, and stability testing of herbal medicines, pharmacovigilance, and dogmatic status of herbal medicines [6]. About 120 plant-derived drugs commonly used in many countries. $74 \%$ were discovered as a result of chemical studies directed by the isolation of the active constituents of plants, which are used in traditional medicine [7].

Several classes of anticancer agents have been developed and many of them are from natural origin. However, a major problem in the use of these agents in cancer treatment is the undesirable side effects produced as a result of non-tumor specificity and multiple-drug resistance. Therefore, in cancer research, traditional medicine has aroused renewed interest in the search for safe, potent, and selective anticancer compounds [8].

\section{METHODS}

\section{Plant material}

The whole plant of Sida acuta was collected from the local areas of Tallarevu (M), Korangi (V), East Godavari Dist., Andhra Pradesh. Identification and authentication of the plant was done by Mr. P. Venu, Additional Director, Botanical Survey of India, Deccan regional Centre, Hyderabad - 500 048. A specimen voucher has been deposited there.

\section{Preparation of extracts}

The whole plant parts of $S$. acuta were shade dried at room temperature and powdered and passed through 60 mesh size sieves. Accurately weight $180 \mathrm{~g}$ of powdered plant parts and extracted with chloroform solvent $(800 \mathrm{ml})$ using cold maceration method. Thus, obtained extract was filtered using Whatman filter paper grade no. 1, followed by concentration of the filtrate. The extract (1.9 g) was shifted to a bottle having screw cap that is previously sterilized and kept in refrigerator by labeling for further use.

\section{Preliminary phytochemical screening}

The chloroform extract was tested for carbohydrates, protein and amino acids, alkaloids, glycosides, flavonoids, tannins, steroids, and saponins [9-18].

\section{Cytotoxic activity}

Chemicals

The chemicals used in in vitro cytotoxic activity are 3-(4,5-dimethyl thiazol-2-yl)-2,5-diphenyl tetrazolium bromide (MTT), fetal bovine 


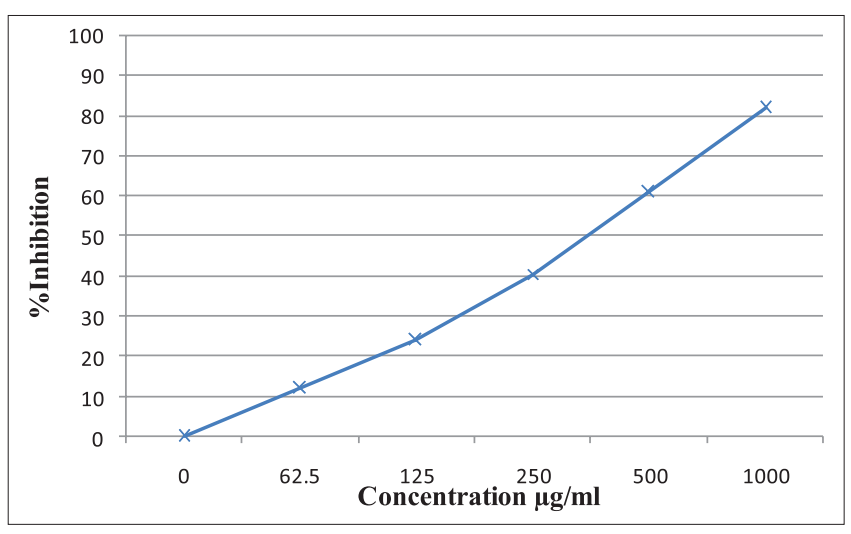

Fig. 1: Cytotoxic activity of Sida acuta Burm.f. on A-431 cell line

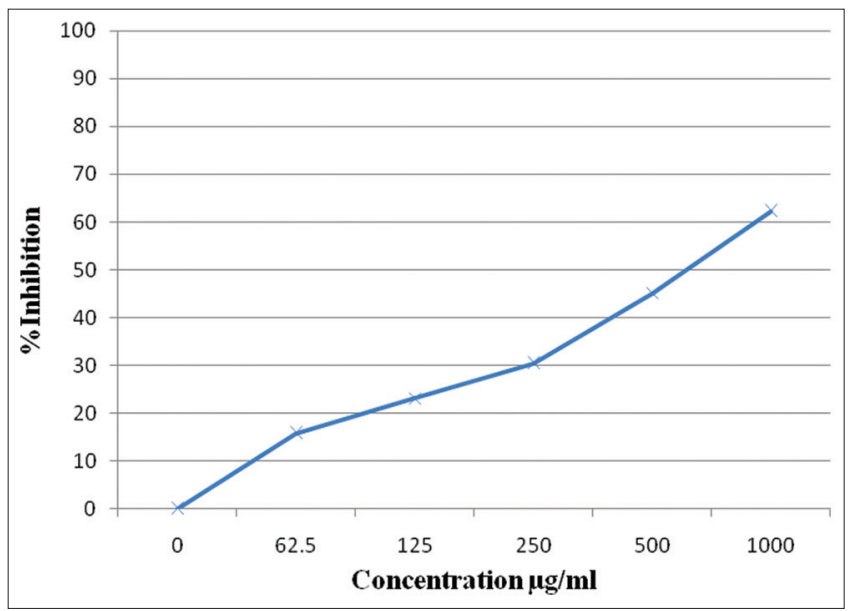

Fig. 2: Cytotoxic activity of Sida acuta Burm.f. on HeLa cell line

serum (FBS), phosphate-buffered saline (PBS), Dulbecco's Modified Eagle's medium (DMEM), and trypsin which were obtained from Sigma Aldrich Co., St Louis, USA. Ethylenediaminetetraacetic acid (EDTA), glucose, and antibiotics were obtained from Hi Media Laboratories Ltd., Mumbai. Dimethyl sulfoxide (DMSO) and propanol were obtained from E Merck Ltd., Mumbai, India.

\section{Cell lines and culture medium}

A-431-human epidermoid carcinoma and HeLa-human cervical cancer cell lines were procured from National Centre for Cell Sciences, Pune, India. Stock cells were cultured in DMEM supplemented with $10 \%$ inactivated FBS, penicillin (100 IU $/ \mathrm{ml})$, streptomycin $(100 \mu \mathrm{g} / \mathrm{ml})$, and amphotericin B (5 $\mu \mathrm{g} / \mathrm{ml})$ in an humidified atmosphere of $5 \% \mathrm{CO}_{2}$ at $37^{\circ} \mathrm{C}$ until confluent. The cells were dissociated with trypsin phosphate versene glucose solution ( $0.2 \%$ trypsin, $0.02 \%$ EDTA, $0.05 \%$ glucose in PBS). The stock cultures were grown in $25 \mathrm{~cm}^{2}$ culture flasks, and all experiments were carried out in 96 microtiter plates (Tarsons India Pvt. Ltd., Kolkata, India).

\section{Preparation of test solutions}

For cytotoxicity studies, weighed test extracts were separately dissolved in distilled DMSO and volume was made up with DMEM supplemented with $2 \%$ inactivated FBS to obtain a stock solution of $1 \mathrm{mg} / \mathrm{ml}$ concentration and sterilized by filtration. Serial two-fold dilutions were prepared from this for carrying out cytotoxic studies.

\section{Determination of cell viability by MTT assay}

The in vitro anticancer activity was determined using MTT assay to measure cell viability.

The monolayer cell culture was trypsinized and the cell count was attuned to $1.0 \times 10^{5}$ cells $/ \mathrm{ml}$ using DMEM containing $10 \%$ FBS.
Every well of the 96-well microtiter plate, $0.1 \mathrm{ml}$ of the diluted cell suspension (approximately 10,000 cells) was added. After $24 \mathrm{hrs,}$ when a partial monolayer was produced, the supernatant was flicked off, the monolayer was washed once with medium, and $100 \mu \mathrm{l}$ of different test concentrations of extracts was added on to the partial monolayer in microtiter plates. The plates were then incubated at $37^{\circ} \mathrm{C}$ for 3 days in $5 \% \mathrm{CO}_{2}$ atmosphere, microscopic examination was carried out, and observations were noted in every $24 \mathrm{hrs}$ interval. After $72 \mathrm{hrs}$, the sample solutions in the wells were discarded and $50 \mu \mathrm{l}$ of MTT in PBS was added to each well. The plates were lightly shaken and incubated for $3 \mathrm{hrs}$ at $37^{\circ} \mathrm{C}$ in $5 \% \mathrm{CO}_{2}$ atmosphere. The supernatant was removed, $100 \mu \mathrm{l}$ of propanol was added, and the plates were smoothly shaken to solubilize the formed formazan. The absorbance was calculated using a microplate reader at a wavelength of $540 \mathrm{~nm}$ [10]. The percentage growth inhibition (PGI) was calculated using the following formula and concentration of test sample needed to inhibit cell growth by $50 \%\left(\mathrm{IC}_{50}\right)$ was generated from the doseresponse curves for each cell line.

$\%$ Growth inhibition $=100-([$ mean occyte diameter (OD) of individual test group/mean OD of control group] $\times 100$ ).

\section{RESULTS AND DISCUSSION}

The preliminary phytochemical study revealed that chloroform extract of $S$. acuta whole plant contains carbohydrates, alkaloids, saponins, fixed oils, tannins, and flavonoids.

In vitro cytotoxic activity of $S$. acuta chloroform extract for the concentrations, 62.5, 125, 250, 500, $1000 \mu \mathrm{g} / \mathrm{ml}$ against A-431-human epidermoid carcinoma and HeLa-human cervical cancer cell lines was studied using MTT assay. There was a gradual less increase in the value of PGI as the concentration of the $S$. acuta extract was increased against A-431-human epidermoid carcinoma and HeLa-human cervical cancer cell lines (Figs. 1 and 2). Effect of inhibition of cell growth showed significantly cytotoxic against A-431 cell lines (human epidermoid carcinoma) with an $\mathrm{IC}_{50}$ of $375 \pm 0.00$ and HeLa cell lines (human cervix carcinoma) with an $\mathrm{IC}_{50}$ of $610.00 \pm 2.5$. The result of cytotoxic activity study in cell lines of the extract indicates that $S$. acuta has anticancer activity against A-431-human epidermoid carcinoma and HeLa-human cervical cancer cell lines.

\section{CONCLUSION}

The present plant S. acuta can be considered as an important source of natural products that have potent cytotoxic activity due to the presence of different phytochemical constituents. Future scope demands that there is a need for the isolation of the constituents responsible for the pharmacological action and to screen the exact mechanism of action for the curative purpose.

\section{ACKNOWLEDGMENT}

We are grateful to the management of Koringa College of Pharmacy, Korangi, Andhra Pradesh, for providing the facilities to complete the work.

\section{REFERENCES}

1. Borlaug N. Realizing the promise of green biotechnology for the poor. Wall St J 2002;13:35-40.

2. Neil MO, Balantidin MF. Human Medicinal Agents from Plants. M.F. ACS Symposium Series. Vol. 48. Washington DC: American Chemical Society; 1993. p. 235-46.

3. De Smet PA. The role of plant-derived drugs and herbal medicines in healthcare. Drugs 1997;54(6):801-40.

4. Gossell-Williams M, Simon OR, West ME. The past and present use of plants for medicines. West Indian Med J 2006;55(4):217-8.

5. World Health Organization. WHO-Technical Report Series. Guidelines for the Assessment of Herbal Medicines. Vol. 863. Geneva: World Health Organization; 1996. p. 178-84.

6. Abhishek K, Ashutosh M, Sinha BN. Herbal drugs-present status and efforts to promote and regulate cultivation. Pharm Rev 2006;6:73-7. 
7. Krishna Kumari GN, Aravind S, Balachandran J, Ganesh MR, Soundarya Devi S, Rajan SS, et al. Antifeedant neo-clerodanes from Teucrium tomentosum Heyne. (Labiatae). Phytochemistry 2003;64(6):1119-23.

8. Chauthe SK, Bharate SB, Periyasamy G, Khanna A, Bhutani KK, Mishra PD, et al. One pot synthesis and anticancer activity of dimeric phloroglucinols. Bioorg Med Chem Lett 2012;22:2251-6.

9. Prema R, Sekar SD, Sekhar KB. Review on: Herbs as anticancer agents. Int J Pharm Ind Res 2011;1:105.

10. Denizot F, Lang R. Rapid colorimetric assay for cell growth and survival. Modifications to the tetrazolium dye procedure giving improved sensitivity and reliability. J Immunol Methods 1986;89(2):271-7

11. Kumar GS, Jayaveera KN, Kumar CK, Sanjay UP, Swamy BM, Kumar DV. Antimicrobial effects of Indian medicinal plants against acne-inducing bacteria. Trop J Pharm Res 2007;6(2):717-23.

12. Parekh J, Chanda SV. In vitro antimicrobial activity and phytochemical analysis of some Indian medicinal plants. Turk J Biol 2007;31:53-8.
13. Edeoga HO, Okwu DE, Mbaebie BO. Phytochemical constituents of some Nigerian medicinal plants. Afr J Biotechnol 2005;4(7):685-8.

14. Akinyemi KO, Oladapo O, Okwara CE, Ibe CC, Fasure KA. Screening of crude extracts of six medicinal plants used in South-West Nigerian unorthodox medicine for anti-methicillin resistant Staphylococcus Aureus activity. BMC Complement Altern Med 2005;5:6.

15. Dahiru D, Onubiyi JA, Umaru HA. Phytochemical screening and antiulcerogenic effect of Mornigo oleifera aqueous leaf extract. Afr J Tradit Complement Altern Med 2006;3(3):70-5.

16. Harborne JB. Phytochemical Methods. $2^{\text {nd }}$ ed. New York, London: Springer, Chapman and Hall; 1984. p. 288.

17. Kanthal LK, Dey A, Satyavathi K, Bhojaraju P. Cytotoxic activity of Lactuca runcinata DC and Gyrocarpus asiaticus Willd on cancer cell lines in-vitro. Int J Pharm Pharm Sci 2014;6(6):457-60.

18. Kanthal LK, Dey A, Satyavathi K, Bhojaraju P. Evaluation of anthelmintic activity of Lactuca runcinata DC and Gyrocarpus asiaticus Willd on Pheritima posthuma. Int J Pharm Pharm Sci 2013;5(4):273-5. 